\title{
Meanings of quality of life for patients with facial melasma
}

Significados da qualidade de vida para pacientes com melasma facial

Significados de la calidad de vida para pacientes con melasma facial

Camila Fernandes Pollo', Luciane Donida Bartoli Miot² , Hélio Amante Miot², Silmara Meneguin ${ }^{1}$

ORCID IDS

Pollo CF (iD https://orcid.org/0000-0003-0264-5841

Miot LDB (iD https://orcid.org/0000-0002-2388-7842

Miot HA (iD https://orcid.org/0000-0002-2596-9294

Meneguin S (D. https://orcid.org/0000-0003-3853-5134

\section{HOW TO CITE}

Pollo CF, Miot LDB, Miot HA, Meneguin S. Meanings of quality of life for patients with facial melasma. ESTIMA, Braz. J. Enterostomal Ther., 16: e3318. https://doi.org/10.30886/estima.v16.626

\begin{abstract}
Objective: To exhibit the meanings attributed to quality of life by patients with facial melasma. Methods: Qualitative research using the focal group technique, with 10 people with facial melasma from a public hospital and private clinic of a municipality in the interior of the state of São Paulo. The methodological indicative used was content analysis. Results: In the interviewees' speech, one perceives the annoyance generated by the opinion of others, with curious and even malicious questions related to the blemish. There is difficulty to hide the injuries and the appearance of skin neglect is also cause for distress for the participants. Conclusion: Because it affects the face, which makes it easily visible, melasma is uncomfortable and has a negative impact on the quality of life, since it affects patients' psychological and emotional well-being.
\end{abstract}

DESCRIPTORS: Quality of life. Melasma. Hyperpigmentation. Nursing.

\footnotetext{
"Universidade Estadual Paulista "Júlio de Mesquita Filho" - Faculdade de Medicina de Botucatu - Departamento de Enfermagem Botucatu/SP - Brazil.

2Universidade Estadual Paulista "Júlio de Mesquita Filho" - Faculdade de Medicina de Botucatu - Departamento de Dermatologia e Radioterapia - Botucatu/SP - Brazil.

Autor correspondente: Silmara Meneguin | Universidade Estadual Paulista "Júlio de Mesquita Filho" - Faculdade de Medicina de Botucatu - Departamento de Enfermagem - Av. Professor Montenegro, s/n | ZIP Code: 18618-000 - Botucatu/SP - Brazil | E-mail: silmeneguin@fmb.unesp.br

Received: Jul. 07, 2018| Accepted: Oct., 102018
} 


\section{RESUMO}

Objetivo: Desvelar os significados atribuídos à qualidade de vida por pacientes com melasma facial. Métodos: Pesquisa qualitativa utilizando a técnica de grupo focal, com 10 pessoas com melasma facial oriundas de hospital público e clínica privada de município no interior do estado de São Paulo. O referencial metodológico utilizado foi análise de conteúdo. Resultados: Percebe-se, na fala dos entrevistados, o incômodo gerado pela opinião de outros, com perguntas curiosas e até maldosas relacionadas à mancha. Há dificuldade para esconder as lesões e a aparência de descaso com a pele também é motivo de angústia para as participantes. Conclusão: Por acometer principalmente a face, o que o torna facilmente visível, o melasma incomoda e tem impacto negativo na qualidade de vida, pois afeta o bem-estar psicológico e emocional dos pacientes.

DESCRITORES: Qualidade de vida. Melasma. Hiperpigmentação. Enfermagem.

\section{RESUMEN}

Objetivo: Desvelar los significados atribuidos a la calidad de vida por pacientes con melasma (también conocido por cloasma) facial. Métodos: Investigación cualitativa utilizando la técnica de grupo focal, con 10 personas con melasma facial oriundas de hospital público y clínica privada de municipio en el interior del estado de São Paulo. El referencial metodológico utilizado fue el análisis de contenido. Resultados: Se percibe, en el habla de los entrevistados, el incómodo generado por la opinión de otros, con preguntas curiosas e incluso maldosas relacionadas con la mancha. Hay dificultad para ocultar las lesiones y la apariencia de la negligencia con la piel también es motivo de angustia para las participantes. Conclusión: Por acometer principalmente la cara, lo que lo hace fácilmente visible, el melasma incomoda y tiene impacto negativo en la calidad de vida, pues afecta el bienestar psicológico y emocional de los pacientes.

DESCRIPTORES: Calidad de vida. Melasma. Hiperpigmentación. Enfermería.

\section{INTRODUCTION}

Melasma is a common, chronic, recurrent pigmentary abnormality characterized by asymptomatic and symmetrical hyperpigmented macules on the skin, particularly on the face. It occurs due to local hypermelanogenesis and affects millions of people around the world ${ }^{1}$. It usually occurs in one of three clinical patterns. The most common is the facial center, while the less common types are malar and mandibular ${ }^{2}$.

Women in fertile age are the most affected and photoexposed areas are the most affected, especially the face $^{3}$. Melasma affects all ethnicities and populations, but epidemiological studies indicate a higher prevalence among more pigmented phenotypes, such as East Asians (Japanese, Koreans and Chinese), Indians, Pakistani, people of the Middle East and Mediterranean Africa. In the Americas, it is common for Hispanics and Brazilians that live in intertropical regions, where there is greater exposure to ultraviolet radiation ${ }^{1,4}$.

Genetic predisposition may be noted with the high incidence of family history of melasma among patients with the disease. In a Brazilian study with 302 women with facial melasma, there was a reference of $47.6 \%$ of firstdegree relatives affected ${ }^{5}$.
Melasma is a disease that is generally difficult to treat, with a long course and frequent exacerbations that may influence patients' perception of quality of life ${ }^{6}$.

Quality of life (QoL) is defined by the World Health Organization (WHO) as the individual's perception of their position in life in the context of the culture and value systems in which they live in relation to their goals, expectations, standards and concerns ${ }^{7}$.

In the context of the clinic, it is related to the repercussion or treatment of diseases that may influence the perception of the concept. In this sense, the impact of the disease on patients' QoL is being increasingly emphasized in therapeutic clinical trials as a relevant outcome ${ }^{8}$.

In the clinical patient, dermatoses can affect selfimage and have great potential to unleash processes that affect self-esteem, contributing to cause feelings that can manifest as anxiety, sadness or even depression. It is known that the intensity of the injury in the QoL is proportional to the time that the affected person coexists with the melasma9.

However, little emphasis has been given to the subjective perception of the individual with melasma in 
relation to their QoL. Most of the studies realize evaluation of the construct through psychometric instruments ${ }^{10}$.

Thus, this research intends to value the singularity of the individual with melasma and, in this way, contribute to the construction of knowledge in the area of nursing in dermatology, based on the experiences of dermatological patients.

\section{OBJECTIVE}

To exhibit the meanings attributed to QoL by patients with facial melasma.

\section{METHODS}

A descriptive, exploratory study with a qualitative approach, realized in a public university hospital in the interior of the state of São Paulo and in a private clinic of the same municipality in March 2014.

Patients with melasma in clinical treatment and older than 18 years were established as inclusion criteria.

After this step, five patients were randomly selected from the list of patients attending the research sites, and then the invitation to participate in the focus group was realized. This method was chosen because it is a technique used to obtain data from previously planned discussions in which the participants express their experiences, values, beliefs and attitudes about specific issues ${ }^{11}$.

In this method, the discussion should be conducted by a moderator for approximately 2 hours in a private setting ${ }^{11}$. The recording of the discussion is realized by an observer who is in charge of monitoring the recording equipment, in an agile and discreet way, aiming not to shift the group's attention to their movements. Also make a brief record in each speech of the participants, to facilitate the later transcription ${ }^{12}$.

Sociodemographic data were collected by means of an instrument developed for the study and obtained from records of medical forms. In the sequence, the focal group was realized, having like guiding questions: 1) In your opinion, does the melasma interferes in the QoL? and 2) Do you think that melasma interferes in which aspects of QoL?
The speeches were recorded and later transcribed using the content analysis of $\mathrm{Bardin}^{13}$. In this technique, after the literal transcription, the pre-analysis is realized, the content organization phase, whose purpose is to systematize the ideas to proceed with the exploration of the material that essentially involves the categorization operation. Finally, in a third moment, data analysis and interpretation occurs.

\section{RESULTS}

Ten patients, all womene, with a mean age of 47.3 years, participated in the study. Of these, five come from private clinics and the other half from the public hospital. As for schooling, five have a medium level, four upper level and only one fundamental level.

To better understand the results, the units of meaning were grouped into three themes: physical aspects/ appearance, clinical treatment and social/emotional aspects with their respective categories. Participants $(\mathrm{P})$ are identified in the text with the numbering assigned to them in the focus group transcript.

From the first theme, physical aspects/appearance, the categories emerged: curious and malicious questions about the blemish, difficulty hiding the injury and appearance of uncared skin.

In the interviewees 'speech, the annoyance generated by the opinion of others, with curious and even malicious questions related to the blemish, can be perceived, since the visible aspect of the skin injuries and their psychological impact interfere in the patients' $\mathrm{QL}^{14}$.

I had the unhappiness of a person speaking: "do you not shave the fuzz?”. (P1)

Hey, you never go to the dermatologist! (P2)

The biggest embarrassment is the person asking you: "About that blemisht, do you not do anything for it?". (P3)

Difficulty in concealing the blemish and appearance of skin neglect also cause distress, as participants report that it is very difficult to find a product that completely covers the blemish, resulting in a careless appearance of skin. 
Some authors describe that skin injuries on the face are more noticeable to the vision of other. Therefore, the visual appearance will play a fundamental role in the perception of oneself ${ }^{15}$.

I already went to do makeup and the person to turn and speak: "there is no way, there is no way to hide". (P2)

I'm going to put something on my face and accentuate the blemish a thousand times more, you can not hide, right? (P5)

In the second theme, the clinical treatments mentioned by the participants, from which the following categories emerged: annoyance with the sunscreen, the treatment itself to lighten the blemishes and the cost of the treatment.

Care with the disease and its treatment also represent difficulties that can impair leisure and work activities ${ }^{16}$.

The participants reported dissatisfaction with the sunscreens available in the market due to the fact that they did not have good coverage; due to the texture of the product does not allow adequate absorption, leaving the skin looking greasy and smeared; and, lastly, because they are not suitable for the skin of Brazilian women, since most of these products are imported

The sunscreens, it are for the European women, American, do not have for the Brazilian woman, do not it? So everything spoil, everything stick, you know? You're well-groomed, but you're melting, so you're going to greet someone, you feel bad about that glue. (P3)

With foundation, if you kiss the person, if the person is clearer than you, that mark is on the person's cheek. (P2)

The home phone, my husband says that everything is white, he complains about having to clean, I end up getting dirty all the time. (P6)

The bleaching treatment itself also generates discomfort and impacts on the QoL of the participants. Some patients reported not adhering to the treatment in the summer because it is so strong that, in addition to leaving the skin red, burned and there is a greater risk of darken the blemish again, the creams used in the treatment dirty and even damage the bedding.
I do not do the treatment in the summer. I walk, I do not have a car, and I'm afraid of getting more blemished if I continue the treatment in the summer. (P3)

Myblemish got worse with the treatment in the summer. By the way, my husband charges me: "but you did it wrong!”. (P6)

The smell bothers me, you're going to give your husband a kiss, you're all stinky. (P7)

It is strong, it even erodes the pillowcase, and the blemish does not pull. (P4)

I had a huge allergy to hydroquinone. (P5)

Skin treatment is very expensive. (P3)

I find it very expensive. (P2)

Sunscreen even if you go to see how much you spend per month ... (P6)

In the third theme, the social and emotional aspects were revealed with their respective categories: annoyance with the veiled look of the other, with photographs and the own image when looking in the mirror.

In a society that values the beautiful and has preestablished esthetic standards, the skin can be considered a business card that attracts, thus, the critical and demanding looks of individuals. When intact and healthy, the skin promotes the relationship between people and facilitates their development in social, emotional and sexual aspects. However, when it is affected by cutaneous affections, it can have serious consequences ${ }^{17}$.

The impression is that people are talking to us and looking straight into it, even if they do not realize it. (P2)

We have the feeling that people are looking at the blemish, not for us, not in people's eyes. (P4)

The picture is very dark. (P3)

When you look in the mirror, you only see the blemish, the rest nothing else catches your attention. (P5) 
The opinion of others does not bother me much, no. I think it's more when I look in the mirror myself. (P3)

\section{DISCUSSION}

The results indicate that melasma is a frequent dermatosis and, because it affects exposed areas, producing the aspect of carelessness and being difficult to camouflage, maximizes its impact on body image and interpersonal relationships. Studies show that patients suffering from this disease feel bored, less attractive and use cosmetics to cover blemishes ${ }^{18}$.

The patient believes that people focus on their skin instead of paying attention to what it is saying, which compromises social and leisure activities. Thus, it is possible to affirm that melasma generates a great impact on the QoL of these patients, since it is a chronic dermatosis and sometimes stigmatizing ${ }^{19,20}$.

Although most dermatological patients do not have fatal diseases, dermatoses often have a major impact on the emotional state, social relations and daily activities of patients, the stigmas caused by very apparent manifestations ${ }^{21}$.

Skin diseases impair self-image and have the potential to lead to depression and anxiety as well as serious systemic diseases. Although not fatal or physically debilitating, they can seriously affect the psychological and social functions of individuals ${ }^{22}$.

In this sense, as a person perceives physical changes in their appearance, this condition can cause suffering and alterations in their life, implying losses in daily routine, socialization and losses in general. Sociological and psychological data increasingly indicate that skin problems can have serious consequences, as they generate shame, anxiety and social embarrassment ${ }^{23}$.

The banalization of the problem can be understood in the light of the traditional educational training in health: the biomedical model. Founded on simplistic and reductionist thinking, it leads the student to a fragmented view of the complexity of life $^{24}$. Studies point out the obstacles of the team in transcending the limits set for their performance ${ }^{25}$.

A study evidences the necessity for education processes directed to health teams focused on the evaluation of melasma, considering that it is a problem of low morbidity, but that it impacts women's QoL 25 .

Melasma causes a negative impact on QoL, mainly due to the face and body image. Due to the dissatisfaction with the appearance, the patients show compromised selfesteem, with repercussions in personal and professional life $^{23}$.

A recent study with a qualitative approach points to data that corroborate the findings of this research ${ }^{26}$.

Because they are apparent, dermatoses easily affect the personal, professional and social life of their patients. In view of this, it is necessary to value the subject aiming at the global evaluation of these individuals.

The lack of studies evaluating the perception of QoL from the perspective of patients was a limitation to compare the findings of this study.

\section{CONCLUSION}

Because it mainly affects the face, which makes it easily visible, melasma bothers and has a negative impact on QoL because it affects patients' psychological and emotional well-being.

Discourses point out that QoL is a subjective conception, linked to values and influenced by the repercussions of the health-disease process in all its dimensions. This fact refers to the necessity not to consider this condition only an esthetic problem.

In this context, nursing can make an important contribution to its action in integral health care, expanding its field of vision and giving meaning to the other's issues as a unique person with their own needs and expectations.

\section{AUTHOR'S CONTRIBUTION}

Conceptualization: Pollo CF; Meneguin S and Miot HA; Methodology, Pollo CF; Meneguin S and Miot HA; Investigation: Pollo CF; Writing - First version, Pollo CF; Writing - Editing: Meneguin S and Miot HA; Supervision: Meneguin S. 


\section{REFERENCES}

1. Brianezi G, Handel AC, Schmitt JV, Miot LD, Miot HA. Changes in nuclear morphology and chromatin texture of basal keratinocytes in melasma. J Eur Acad Dermatol Venereol. 2015;29:809-12. https://doi.org/10.1111/jdv.12453.

2. Tamega AA, Miot LBD, Bonfiete C, Gige TC, Marques ME, Miot HA. Clinical patterns and epidemiological characteristics of facial melasma in Brazilian women. J Eur Acad Dermatol Venereol. 2013;27:151-6. https://doi.org/10.1111/j.14683083.2011.04430.x

3. Handel AC, Lima PB, Tonolli VM, Miot LD, Miot HA. Risk factors for facial melasma in women: a case-control study. Br J Dermatol. 2014;171:588-94. https://doi.org/10.1111/ bjd.13059.

4. Sociedade Brasileira de Dermatologia. Perfil nosológico das consultas dermatológicas no Brasil. An Bras Dermatol. 2006; 81:549-58. https://doi.org/10.1590/S0365-05962006000600005.

5. Corrêa MP, Pires LCM. Doses of erythemal ultraviolet radiation observed in Brazil. Int J Dermatol. 2013;52(8):96673. https://doi.org/10.1111/j.1365-4632.2012.05834.x

6. Cestari TF, Hexsel D, Viegas ML, AlmeidaART, Mendes AMD, Filho JWA, et al. Validation of a melasma quality of life questionnaire for Brazilian Portuguese language: the MelasQoL-BP study and improvement of QoL of melasma patients after triple combination therapy. $\mathrm{Br} J$ Dermatol. 2006;156(1):13-20. https://doi.org/10.1111/j.1365-2133.2006.07591.x.

7. The World Health Organization Quality of Life Assessment (WHOQOL): position paper from the World Health Organization. Soc Sci Med. 1995;41:1403-9.

8. Romero M, Vivas-Consuelo D, Alves-Guzman N. Is Health Related Quality of Life (HRQOL) a valid indicator for health systems evaluation? Springerplus. 2013;2(1):664-70. https:// doi.org/10.1186/2193-1801-2-664.

9. Taborda MLW, Weber MB, Freitas ES. Avaliação da prevalência de sofrimento psiquico em pacientes com dermatoses do espectro dos transtornos psicocutâneos. An Bras Dermatol. 2005;80:351-4. https://doi.org/10.1590/ S0365-05962005000400004

10. Padilha S, Noronha APP, Fagan CZ. Instruments for psychological assessment: use and referee by psychologists. Aval. psicol. 2007;6(1):69-76

11. Beck CLC, Gonzales RMB, Leopardi MT. Técnicas e procedimentos de pesquisa qualitativa. In: Leopardi MT. Metodologia da pesquisa na saúde. Santa Maria: Palotti; 2001. p. 223-44.

12. Dall'Agnol CM, Trench MH. Grupos focais como estratégia metodológica em pesquisas na enfermagem. R. gaúcha Enferm. 1999;20(1):5-25.

13. Bardin L. Análise de conteúdo. Lisboa: Edições 70; 2009.
14. Ludwig MWB, Muller MC, Oliveira MS, Moraes JFD. Qualidade de vida e localização da lesão em pacientes dermatológicos. An Bras Dermatol. 2009;84(2):143-50. https://doi.org/10.1590/S0365-05962009000200007.

15. Jesus PBR, dos Santos I, Brandão ES. La autoimagen de símismo y la autoestima de las personas com transtornos de piel: uma revisión integradora de la literatura la luz de la teórica Callista Roy. Arquichan. 2015;15(1):75-89. https:// doi.org/10.5294/aqui.2015.15.1.8.

16. Alves GF, Nogueira LSC, Varella TCN. Dermatologia e gestação. An Bras Dermatol. 2005;80(2):179-86.

17. Taylor A, Pawaskar M, Taylor SL, Balkrishnan R, Feldman SR. Prevalence of pigmentary disorders and their impact on quality of life: a prospective cohort study. J Cosmet Dermatol. 2008;7(3):164-8. https://doi.org/10.1111/j.14732165.2008.00384.x

18. Scherdin U, Burger A, Bielfeldt S, Filbry A, Weber $T$, Scholermann $A$, et al. Skin-lightening effects of a new face care product in patients with melasma. J Cosmet Dermatol. 2008;7(1):68-75. https://doi.org/10.1111/j.14732165.2008.00364.X

19. Finlay AY, Khan GK. Dermatology Life Quality Index (DLQI): a simple practical measure for routine clinical use. Clin Exp Dermatol. 1994;19(3):210-6.

20. Abdel-Hafez K, Mahran AM, Hofny ER, Mohammed KA, Darweesh AM, Aal AA. The impact of acne vulgaris on the quality of life and psychologic status in patients from upper Egypt. Int J Dermatol. 2009;48:280-5. https://doi.org/10.1111/ j.1365-4632.2009.03838.x.

21. Ozelame DM. Pensamento complexo, educação e aprendizagem. Revista Espaço Acadêmico. 2015;15(170):80-6.

22. Tasoula E, Gregorius S, Chalikias J, Lazarou D, Kanopoulou I, Katsambas A, et al. The impact of acne vulgaris on quality of life and psychic health in young adolescents in Greece. Results of a population survey. An Bras Dermatol. 2012;87:862-9. https://doi.org/10.1590\%2FS0365-05962012000600007.

23. Miot LBD, Miot HA, Silva MG, Marques MEA. Fisiopatologia do melasma. An Bras Dermatol. 2009;84(6):623-35. https:// doi.org/10.1590/S0365-05962009000600008.

24. Belletti MUM. Conhecimento, atitude e prática da equipe de saúde sobre melasma na gravidez. Av Enferm. 2018;36(1):409. https://doi.org/10.15446/av.enferm.v36n1.58896.

25. Parada M, Teixeira SP. Maquiagem e camuflagem. São Paulo: Moreira Jr; 2010.

26. Jiang J, Akinsseye O, Tovar-Garza A, Pandya AG. The effect of melasma on self-esteem: a pilot study. Int J Women Dermatol. 2018;4(1):38-42. https://doi.org/10.1016\%2Fj. ijwd.2017.11.003. 